\title{
Persuasiveness in Political Discourse on Twitter
}

\section{Персуазивність у жанрі твіттінг в англомовному політичному дискурсі}

\author{
Olena Goroshko ${ }^{1}$ \\ HabDoc in Philology and \\ Sociology, Professor, Chair holder \\ of Cross-Cultural and Foreign \\ Languages Department
}

\begin{abstract}
Олена Горошко ${ }^{1}$
доктор філологічних наук, доктор соціологічних наук, професор, завідувач кафедри міжкультурної комунікації та іноземних мов
\end{abstract}

\section{E-mail: olena_goroshko@yahoo.com orcid.org/0000-0002-8592-1022}

Tetiana Poliakova ${ }^{2}$

Ph.D. in Philology,

Assistant Professor,

Chair holder of the Department

of Language Training

\section{Тетяна Полякова ${ }^{2}$}

кандидат філологічних наук, доцент, завідувач кафедри мовної підготовки

\section{E-mail: tatyana kharkov@outlook.com orcid.org/0000-0002-3353-2228}

\section{${ }^{1}$ National Technical University «Kharkiv Polytechnic Institute» 2, Kirpichov Str., Kharkiv, Ukraine, 61002}

${ }^{2}$ Kharkiv Petro Vasylenko National Technical University of Agriculture

44, Alchevsky Str., Kharkiv, Ukraine, 61002
${ }^{1}$ Наиіональний технічний університет «Харківський політехнічний інститут» $\triangle$ вул. Кірпічова, 2, м. Харків, Україна, 61002

2 Харківський національний технічний університет сільського господарства ім. П. Василенко $\square$ вул. Алчевського, 44, м. Харків, Україна, 61002

Original manuscript received April 29, 2018

Revised manuscript accepted September 25, 2018 


\section{ABSTRACT}

The article focuses on the question of new communication form appearance the internet communication, namely political internet communication, that furthermore influenced the appearance of the new genres, among which we can find twitting. The active twitting usage with the communicative aim in political sphere puts the question about language learning namely about the means of expression of the persuasive language influence in the analyzed genre, as the persuasive language influence function is one of the most important functions in political internet-communication from psycholinguistic point of view.

The research process found out the range of verbal expression meanings of explicit and implicit persuasiveness. To the verbal meanings of implicit persuasiveness, we can refer the usage of imperatives and imperative constructions, explicit performatives, constructions with modal verbs, short sentences, and slogans.

The verbal meanings of implicit persuasiveness include rhetorical questions, affirmative sentences, and famous people's citations. To the special language meanings, which encourage the influence on the addressee we also refer the usage of elliptical sentences, parcelation, repetition. The mostly used lexical and stylistic meanings, that encourage the fulfillment of the main purposes of political discourse is the usage of metaphor, metonymy, irony, personification and oxymoron. The research allowed us to come to conclusion, that the English-speaking political internet-communication is characterized with the usage of the same verbal appellation meanings as traditional communication. But we can also outline the meanings peculiar only to the internet communication and especially the twitting genre. For the research methodology we took out modern scientific conceptions. The research methodology was developed according the framework of genre study, psycholinguistics, 2.0, virtual genre study. According to the aim and tasks, general and linguistic research methods were used.

Key words: communication from the keyboard and voices (sounds) - to the screen and voice (sound), psycholinguistics 2.0, political internetcommunication, internet-genre, twitting, persuasiveness.

\section{Introduction}

The study further presented in this article is embedded into the notion of computer-mediated communication, a term that became widely known in linguistics (Herring \& Androutsopoulos, 2015; Thurlow et al., 2004), after it appeared in the title of an influential online publication, the Journal of Computer-Mediated Communication (Crystal, 2011: 1) and in the work of Nancy Baron (Baron, 1984). According to 
Kompantseva (2008), computer-mediated communication is defined as a special form of communication, interaction of people with each other on the Internet, carried out by means of exchanging text and multimedia messages. There are a number of seminal studies that address the issue of computer-mediated communication (Akimova, 2012; Baron, 2003; 2008; Barkovitch, 2015; Herring, 2014) by means of elucidating such topics as vocabulary use, oral-written format of speech, genre, genre aspects, word-building, (Crystal, 2011; Herring, 1996; 2008).

In order to provide insight into the new trends in Internet linguistics, including psycholinguistic research as one of its subject areas, and under impact of the rapid development of Internet technology especially web 2.0 platforms (Herring, 2013), the term linguistics 2.0 is coined to delineate all these innovative processes taking place in the communicative space. In 2012 the umbrella term keyboard (voice) - to - screen (voice) communication appeared to cover those types of communication that may be depicted through a number of specific dichotomies: asynchronous - synchronous; written - spoken; monologue - dialogic; text - utterance; private - public; mobile stationary, monomodal - multimodal and voice - keyboard (screen) (realized through Telegram or WhatsUp messengers or Twitter or Facebook SNS (Goroshko, 2017). The terms psycholinguistics 2.0 or even psycholinguistics 3.0 are also suggested to specify a separate field of linguistics analysis covering psycholinguistic research directly impacted by web 2.0 or web 3.0 technologies, e.g. the use of web 2.0 technologies in language acquisition studies, or impact of political leaders' speech on the citizenry, etc. (Goroshko, 2009). Thus, enlightening the new trends in Internet linguistics associated with the rapid development of Internet technology for the formalization of these innovative processes one can recommend to use an umbrella term keyboard (voice) - to - screen (voice) communication, covering all these types of communication through the Net.

Research in online communication typically involves text comments on photo-sharing sites; text, audio, and video responses to YouTube videos; text (and voice) chat during multiplayer online games; and text, video and audio messages from mobile phones posted to interactive TV programs, through messengers as Telegram or Viber, etc. These types of communication are characterised by convergence processes 
that involve the convergence of text with text, text with multimodality (video or audio), comments on news stories; 'talk' pages associated with Wikipedia articles; status updates and comments convergence of different layers in texts, time overlaps, the senders and receivers of the messages we can trace the trend of increasing convergence, provoked even a specially developed research methodology (Snelson, 2016).

In order to describe the psycholinguistic component in online communication realized with the help of web 2.0 platforms and gadgets we propose to use the term psycholinguistics 2.0 that emphasizes the psycholinguistic research component in this process. This term should be regarded in conjunction with a new approach in linguistics called Internet linguistics, a new area of linguistics with its own proper methodology and research objects (Goroshko, 2009). Consequently, the Internet and social media (web 2.0 platforms) have given rise to a broad range of new communicative genres that are referred to under the term genre 2.0. One can mention such genres as chats, forums, text messaging (SMS, WhatsApp), interaction on wiki talk pages and in blog comments, via Twitter, on social network sites, e.g. Facebook or Pinterest, and in multimodal $3 \mathrm{D}$ environments.

\section{Theoretical background}

Humanity has ample access to the opportunities offered by Internet-technologies (Herring, 2015) and it is only natural that political leaders use tremendous advantages associated with the development of information technologies and, in particular, social media resources. Being actively introduced into the sphere of politics, information technologies have significantly changed people`s views and stereotypes about the processes of interaction between political leaders and society. Special terms, such as network politics, political Internet, cyberpolitics, digital democracy, politics 2.0, communication democracy, cyber democracy, e-government, computer-mediated political communication (Morozova, 2011: 156; Goroshko \& Chevordov, 2017) appeared to identify a new reality, new ways of the development of society and states. The presence of political discourse on the Internet has facilitated the emergence of political linguistics. It is a research area that deals with political communication, i.e. verbal activity which is focused on the propaganda of certain ideas with an emotional impact on the citizenry. This social science appears at the crossroad of linguistics and political 
studies. Scholarship in this field is united, first of all, by the material under examination, namely the political language, texts, and discourse (Chudinov, 2012: 6).

It is an area where political linguistics is closely connected with psycholinguistics, which examines the relationship between language, thinking, and consciousness. The relationship of these two fields is stipulated by the fact that one of the directions of psycholinguistics study is the analysis of speech activity functions. In the political sphere of communication we can distinguish informative, suggestive, expressive, persuasive, and culture forming functions. The focus of attention of psycholinguistics is on the analysis of the relationship between messages, author's intentions, their transformation into verbal texts and their subsequent interpretation by the addressee. Perception of speech implies extracting the meaning that lies behind the external form of the statement. In the political sphere this process gains even more importance, since one of the main tasks of political leader is to bring his/her idea, and intention to the addressee using both explicit means and implicit ones, to encourage the addressee to perform a certain action.

The transition of political communication from the traditional to the virtual sphere facilitated the emergence of political Internet-linguistics. Its main objective is to study political texts and the peculiarities of the language functioning in the political sphere on the Net. The emergence of Internet-communication, including political Internet-communication, initiates new genres actively used on the Net, one of which is twitting, a digital genre initiated by the Internet-service Twitter. Twitter is a social network, an online service for micro-blogging, allowing users to send short (up to 280 characters) text messages.

Today, it is common for political leaders, government officials, political parties (i.e., all political stakeholders) to use Twitter in order to convey their official positions to the world community. One of the first leaders who started using Twitter in 2007 was the 44th US President Barack Obama. Currently, the most popular political leaders (by the number of followers) who have their accounts on Twitter are Donald Trump, the 45th US President (about 53 million); Narendra Modi, Indian Prime Minister (about 43 million); Barack Obama, the 44th US President (more than 100 million), and other political actors.

Being a powerful interactive means of communication with the society, the Internet makes it possible for politicians to carry on a steady 
dialogue with their Internet-users, express their opinion on various political issues, and realize their personal ambitions and qualities in the field of politics. It allows strengthening and promoting their own image and glory (Page, 2012). The implementation of this communication is facilitated by the use of the following Twitter functions: the use of @ in front of the name indicates that this tweet is intended for a particular user; letters $R T$ denote the quotation of another user; the sign of hashtag (\#) denotes a thematic word. All functions mentioned above can be used in the genre - twitting - in order to promote your image, to show, for example, your connection with other users or your importance (by the number of retweets).

An active use of the Internet for communication in the political sphere raises the question of studying the means of expressing persuasiveness in the genre under investigation since one of the most essential areas of psycholinguistics (as one of the fields of linguistics, political linguistics) is the analysis of language as the main means of conducting speech activity, the main means of communication. However, psycholinguistics is interested not only in the study of linguistic means, e.g. grammatical, lexical, morphological, syntactic, but in the processes of speech activity in the system of various types of human activity, in this case, in the sphere of political discourse.

The study of political Internet discourse attracted researchers in political sciences, sociology, sociolinguistics, and psycholinguistics (Bronnikov, 2011; Chudinov, 2012; Conover et al., 2011; Haynes, 2009). The attention of linguists usually concentrates on the traditional political communication (Vashyuk, 2014; Petlyuchenko, 2009; Popova, 2014). As far as political Internet discourse is concerned (Morozova, 2011; Himelboim et al., 2013; Lehti \& Laippala, 2014), and namely the study of the linguistic peculiarities of the genre twitting in the field of political Internet-communication, there are not many works on this topic today.

The research purpose of the study further presented in the article is to analyze the ways of expressing persuasiveness in the genre of twitting in the English-speaking political discourse on the Net. The research objectives are to determine and analyze the main explicit and implicit means of expressing persuasiveness in the genre twitting. The research material includes 915 messages obtained from official home pages of five most popular (according to the number of followers) politicians on Twitter - Donald Trump, Narendra Modi, Shashi Tharoor, 
Cory Booker, and Paul Ryan. The messages are collected during the period from June 1 to June 302018.

To meet our objectives the method of information analysis, the synthesis method, the comparative method, the method of linguistic description, semantic and syntactic methods, interpretation method, the mixed methods of quantitative and qualitative analyses are used.

\section{Results and discussion}

The organization of the text in the area of politics depends, first of all, on the target audience - the addressees, who are presented by like-minded people of the politician, their opponents and potential electors (Chudinov, 2012). In addition, an important role is attributed to the purpose of using the Internet in the politics. Similar to traditional mass media, it is the dissemination of information from the author to addressees. However, in contrast to traditional communication, where this process is basically unidirectional, in Internet-communication, thanks to the use of modern technologies and, in particular, the original functions of the genre twitting - the use of thematic words, retweets, the ability to address a tweet both to a particular user, and to all users signed to receive messages from this author, it becomes a dialogue - an interaction that strengthens the trust and mutual understanding among communicants. Being closely connected with the issues of ideology (problems of covering political, economic, cultural life, international relations, etc.), communication on the Internet is also aimed at explaining and evaluating information and political situations.

However, one of the most important functions of political Internet discourse is the function of the linguistic persuasion (it is also called motivation, vocative, conative, regulative (Chudinov, 2012), appellative function (Chudinov, 2012; Petlyuchenko, 2009) as the Internet is considered to be an important and effective tool to construct opinions and worldviews, i.e. it presents a powerful tool to impact the audience (Morozova, 2011: 156-157), a tool of persuasion, reasoning and propaganda, which is used to meet individual objectives.

Persuasiveness in political discourse on Twitter implies an impact on the addressee for the purpose of mobilizing them to perform certain actions. Citizenry is urged to transfer the power to a particular party, to give support to this party, to act in accordance with the decisions taken by this party (Chudinov, 2012: 84). Persuasiveness in political 
discourse on Twitter is aimed at addressing the users to come to the elections, to vote for a particular political party and a politician, to take part in meetings, etc. Persuasiveness is realized with the help of various linguistic means.

Research has distinguished between two types of means, for instance an explicit appeal to commit an action. It is such a type of an appellative statement that is associated with the change in behavior or the way of thinking. The second one is an implicit type of an appellative statement associated with a hidden message (Petlyuchenko, 2009: 203). Verbal means of explicit persuasiveness include imperatives, illustrated by the following tweet:

(1) NarendraModi@narendramodiJun26

The interaction with beneficiaries of the Government's social security schemes commences at 9:30 AM. Do join via the 'Narendra Modi Mobile App' or watch it on @DNewsLive. The stories of the beneficiaries will surely motivate us all.

This message is an example of the use of the imperative mood directed at the addressee and aimed to induce him to perform the action you need. As the study showed, imperatives ( 82 cases) are the most frequent form of verbal means of explicit persuasiveness and are found in about $9 \%$ of the tweets under investigation. Imperative constructions which include the use of such constructions as it is time for smb to do smth, to let smb do smth, etc.:

(2) Donald J.Trump@realDonaldTrump Jun 26

Thank you South Carolina. Now let's get out tomorrow and VOTE for@HenryMcMaster!

This tweet presents an example of the use of the imperative construction, the percentage of which in the tweets of the political sphere is about 2\% (19 cases). The widespread use of imperatives and imperative constructions as special means of appeal is caused by the author's orientation both on the appellative and contact form of the statement (Petlyuchenko, 2009: 211).

Explicit performatives include the verbs to appeal, to ask, to request, to order, to urge, to demand, to want, to wish, to entrust, to advise, to recommend:

(3) NarendraModi@narendramodiJun20

I urge people around to world to embrace Yoga. I also request people to share the joys of Yoga with others by teaching 
Yoga particularly to today's youth. This way we can create a healthier planet.

In this message, performative explication is realized by using the verbs urge and request. According to the analysis, the use of explicit performatives was found in about $1.7 \%$ of the tweets of the political sphere.

Constructions with modal verbs (must, should, to have to, need, can, could), which are the most effective way of appealing to the addressee associated with the recommendation to perform the action:

(4) ShashiTharoon @ShashiTharoorJun 18

Interesting analysis by AmnaMirza on the lateral entry issue. My view is that there should be clear criteria for which posts are thrown open for lateral entrants who have expertise unavailable in government. \&objective evaluation standards for applicants.

The use of the modal verb in this example indicates the wishes of the politician, his intentions, and is also characterized by the imperative nature and increased ideological value in the sphere of political communication.

The afore-mentioned tweets are characterized by the prevalence of the use of the modal verb must $(40 \%$ of all modal verbs aimed at inducing the addressee to perform an action). The second place among modal verbs as for the frequency of their use is taken by the verb should (about 35\%), followed by the verbs need (9\%), to have to $(9 \%)$, can, could $(7.7 \%)$, supporting the main objective of the statement and expressing the desire or need to perform an action (Didenko, 2001: 94-95).

In general, modal verbs are found in about $8.5 \%$ of the tweets under investigation. This percentage indicates a fairly high level of their use and is explained by the need to implement an incentive to perform an action.

Another linguistic means of persuasiveness in political discourse on Twitter is represented by short sentences and slogans:

(5) Donald J.Trump@realDonaldTrump Jun 4

Farmers have not been doing well for 15 years. Mexico, Canada, China and others have treated them unfairly. By the time I finish trade talks, that will change. Big trade barriers against U.S. farmers, and other businesses, will finally be broken. Massive trade deficits no longer! 
These verbal means of explicit persuasiveness are used in $3 \%$ of the messages of political discourse on Twitter, which generally indicates quite a high level of their use due to the ability to attract users' attention to this part of the message and thus focus on a particular problem.

Verbal means of implicit persuasiveness involve affirmative sentences, e.g.

(6) NarendraModi@narendramodiJun30

GST has brought growth, simplicity and transparency. It is: Boosting formalisation. Enhancing productivity. Furthering 'Ease of Doing Business.' Benefitting small and medium enterprises. \#GSTForNewIndia

This tweet is an example of an affirmative sentence - the statement of the political leader, their judgment, attitude to a particular issue and the purpose of which is to try to convince users of his point of view. Affirmative sentences are one of the most widespread verbal means of implicit persuasion in political online and offline communication. They occur in $17 \%$ of the messages studied and head the list in the frequency of use among verbal means of implicit persuasiveness.

Interrogative sentences, mainly rhetorical questions, help to draw attention to a certain problem, to show the solidarity of the political leader with his voters, to pay attention to his candidature, etc.:

(7) ShashiTharoor@ShashiTharoorJun26

Sorry to hear that the Indian Govt has not raised the student visa issue w/ the British: https://indianexpress.com/article/india/nobodyfrom-govt-has-raised-student-visa-row-with-us-british-envoy-dominicasquith-5232053/...Chinese applicants get more student visas, more cheaply \& for longer duration, on less onerous terms, than Indian students do. Does our Govt have no self-respect?

The use of rhetorical questions is an important means of dialogization consolidating the space between the author and other users. One of its functions is to attract attention, to deepen the impression, to increase the emotional tone (Arnold, 1990: 167). The answer to the rhetorical question has already been prompted by the authors. They intend only to induce the addressee to perform an action, to make him an active participant of communication. As the study has shown, rhetorical question are found in about 32 messages, or $3.5 \%$ of all tweets in this study. 
Future tenses is the second most frequently used tool of verbal means of implicit persuasiveness (about 5.7\% of messages). Using future tense forms, the author tries to make predictions concerning different situations in the future, expresses his ideas about future events. Thus, comparing past situations, past experience with possible future events is a powerful method of argumentation to meet communicative objectives, for instance

(8) Donald J.Trump@realDonaldTrump Jun 30

I will be making my choice for Justice of the United States Supreme Court on the first Monday after the July 4th Holiday, July 9th!

Another means of persuasiveness is to quote the sayings of famous writers, politicians, journalists, etc.:

(9) CoryBooker@CoryBookerJun29

"Not everything that is faced can be changed, but nothing can be changed until it is faced.» James Baldwin \#FaceIt \#FightIt \#YouFindHopeThroughStruggle

In (9), the author uses the statement by James Baldwin, a famous American writer and playwright of the $20^{\text {th }}$ century. It introduces new meanings, new events into historical and cultural context (Valgina, 2003: 150). Being an important functional element of verbal persuasiveness, citations help to increase the verbal representativeness of the text, the expressiveness of messages. This means of implicit persuasiveness is found only in about $1.2 \%$ of tweets. It can be explained by the restriction of messages in the genre twitting up to 280 characters, and also depends on the linguistic identity of the politician, i.e. it is of individual nature and is a feature of the author's writing style. Thus, $91 \%$ of all citations that occur in the messages examined are found in the tweets by D. Trump.

Special linguistic means, which strengthen the impact on the addressee, also include (Chudinov, 2012: 106) elliptical sentences, representing the omission of the main members of the sentence, e.g.

(10) Donald J. Trump@realDonaldTrump Jun 25

Just landed in South Carolina - will be at the McMaster rally shortly! \#MAGA

Elliptical sentences rank quite high among verbal means of expressing persuasiveness and are found on average in $28 \%$ of tweets investigated. It is explained by the fact that in the genre under study, as in many other digital genres characterized by a synchronous nature 
of communication, elliptical sentences create an imitation of a lively, informal conversation, give it the inflection of emotionality, thus bringing the author and the recipient closer, which is extremely important in the field of political communication when achieving the goals set.

Parceling presents an important stylistic technique of syntax that allows attracting users' attention and conveying them your point of view. However, in the genre twitting in the field of political communication, there are only a few cases of using this means - in about $0.5 \%$ of messages, e.g.

(11) Narendra Modi@narendramodiJun26

India is among the most investor friendly global economies. Our country offers: Growth. Macro-economic stability. Supportive regulatory framework. Political stability. A talented workforce. Large markets. Good physical infrastructure. Come, invest in India!

Repetition is found quite rarely - in $0.8 \%$ of tweets, repetition is an expressive means of syntax aimed at attracting the addressee's attention and emphasizing the emotional and semantic tone of the statement:

(12) Cory BookerVerified account @CoryBooker Jun 22

Love over hate Love over indifference Love over ignorance Love over ego Love over fear Love over barriers Love over borders Love over And over And over Again

In the present corpus, there are other lexical stylistic means that contribute to the impact on the audience, its opinions, the implementation of the strategies of positive self-presentation and negative representation of the opponent, etc. - are revealed. One of those means is metaphor and metonymy, e.g.

\section{(13) Donald J.Trump@realDonaldTrump Jun 7}

Prime Minister Trudeau is being so indignant, bringing up the relationship that the U.S. and Canada had over the many years and all sorts of other things...but he doesn't bring up the fact that they charge us up to 300\% on dairy - hurting our Farmers, killing our Agriculture!

(14) NarendraModi@narendramodiJun 24

A test match in Bengaluru drew the attention of the entire cricketing world. The match between India and Afghanistan scripted history and marked a win for sportsmanship. \#MannKiBaat

The data analysis indicates that irony is present in political discourse on Twitter, e.g. 
(15) ShashiTharoor@ShashiTharoorJun30

Wonderful discussion on The Role of Empire in WW1 at the \#BradfordLiteraryFestival today with @RemonaAly, LucFerrier, PatCumper \& @AmanMadra Britain is waking up to how much the soldiers of the non-white colonies did for her in two World Wars. Better late than never.

As the analysis shows, the use of lexical stylistic means cannot be assigned to the most common means of expressing persuasiveness in political discourse on Twitter. Thus, these means are found in $10.2 \%$ of the messages under study. The use of metaphor and metonymy is found in $82 \%$ of the tweets, and irony in $18 \%$. It is explained by the fact that the main function of the genre studied is informing users about plans, meetings, various events and the use of linguistic means (the above mentioned lexical stylistic means) that enhance expressiveness of statements is not always justified in view of the sphere of the genre under study. A low frequency of metaphor, metonymy, irony and other tropes is also explained by the limitation of the size of the message in the genre twitting up to 280 characters.

\section{Concluded}

It can be concluded that political discourse on Twitter is characterised by a fixed number of verbal means of explicit and implicit persuasiveness. The use of linguistic means is manifested at all linguistic levels, lexical, morphemic, and syntactic. In general, these means are found in $90.5 \%$ of the tweets, which indicates a high frequency of their use in the genre twitting in this area. The first three places as for the frequency of use are taken by elliptical sentences ( $28 \%$ of messages), followed by affirmative sentences (16.4\% of messages) and imperatives ( $9 \%$ of messages).

It can be argued that political Internet discourse is characterized by the use of the same verbal means as in traditional communication. However, it is also possible to single out the means that can be found exclusively in Internet discourse, and namely, in twitting, and the use of which became possible only due to unlimited possibilities of information technologies. These are the use of thematic words that allow getting to the timeline where this particular topic is discussed; the use of letters RT, the sign @, the ability to use links to audio and video materials and many others. 
Thus, Internet technologies provide an opportunity to significantly expand the range of means used by political leaders in the course of their activity, to make it more expressive, which is as important as the content of the text itself.

So, the issues that constitute the core of psycholinguistics, political Internet-linguistics, and one of which is studying genre diversity of Internet-communication, the analysis of verbal and non-verbal means of the genre structure, are extremely complex and diverse. A careful analysis of linguistic resources, which provide an important means of struggling for political power, will contribute to a better understanding and analysis of texts of different genres in political communication, which determines the prospects for further studies of political Internet-communication, digital genres, genres 2.0 in synchronic and diachronic aspects.

\section{References}

Akimova, N.V. (2012). Istoriya issledovaniya yazyka Interneta v Ukraine [The history of Internet language studies in Ukraine]. Russkaya filologiya - Russian Philology, $1-2,55-59$ [in Russian].

Arnold, I.V. (1990). Stilistika sovremennogo angliyskogo yazyka: (Stilistika dekodirovaniya) [Stylistics of modern English: (Decoding stylistics)]. Moscow : Prosveshcheniye [in Russian].

Barkovitch, A.A. (2015). Kompyuterno-oposredovannaya kommunikatsiya [Computermediated communication]. Vestnik Udmurtskogo universiteta. Seriya "Istoriya $i$ filologiya»-Bulletin of Udmurt University. Series «History and Philology», 3, 97-101 [in Russian].

Baron, N.S. (1984). Computer mediated communication as a force in language change. Visible Language, XVIII (2), 118-141.

Baron, N.S. (2003). Language of the Internet. The Stanford Handbook for Language Engineers, (pp. 59-127). Stanford : CSLI Publications.

Baron, N.S. (2008). Always on. Language in an Online and Mobile World. Oxford : Oxford University Press.

Bronnikov, I.A. (2011). Osobennosti seti Internet kak formy politicheskoy kommunikatsii [Features of the Internet as a form of political communication]. Extended abstract of candidate's thesis. Moscow : MosSU [in Russian].

Chudinov, A.P. (2003). Metaforicheskaya mozaika v sovremennoy politicheskoy kommunikatsii: Monografiya [Metaphorical mosaic in modern political communication: Monograph]. Yekaterinbutg : UralSPU [in Russian].

Chudinov, A.P. (2012). Politicheskaya lingvistika: uchebnoye posobiye [Political linguistics: A student guide]. Moscow : Phlinta [in Russian].

Conover, M.D., Ratkiewicz, J., Francisco, M., Concalves, B., Flammini, A., \& Menczer, F. (2011). Political polarization on Twitter. Proceedings of the fifth international AAAI conference on Weblogs and Social Media. Retrieved from http://www.aaai.org/ocs/index.php/ICWSM/ICWSM11/paper/view/2847/3275. 
Crystal, D. (2011). Internet linguistics: A student guide. London and New York : Routledge. Taylor \& Francis Group.

Deneke, L. (2007). Computer-mediated communication: potential and actual effects on the English language. Saarbrücken : VDM Verlag Dr. Mueller.

Didenko, M.A. (2001). Politicheskoye vystupleniye kak tip teksta [Political speech as a type of text]. Candidate`s thesis. Odessa : OdesNU [in Russian].

Goroshko, O.I. (2009). Ot psikholingvistiki 2.0 do psikholingvistiki 3.0: Quo Vadis? [From psycholinguistics 2.0 to psycholinguistics 3.0: Quo Vadis?]. Psikholingvistika - Psycholinguistics, 3, 108-124 [in Russian].

Goroshko, O.I. (2017). Internet linguistics: from metaphor to discipline? Aktualni napryamy suchasnoyi filolohiyi - Actual Fields of Modern Philology: Proceedings of the International Virtual Scientific and Practical Conference Dedicated to $15^{\text {th }}$ Anniversary of the Foundation of the International Humanitarian University, (pp. 25-31). Odessa: OdesHU.

Goroshko, O.I., \& Chevordov, Yu.A. (2017). Polityka 2.0 u diyi (sotsiolohichnyy vymir) [Politics 2.0 in use (sociological dimension]. Sotsialni komunikatsiyi: teoriya $i$ praktyka - Social Communications: Theory and Practice, 5, 16-25 [in Ukrainian].

Haynes, A.A. (2009). Making an impression: New Media in the 2008 presidential nomination campaigns. P.S. Political Science and Politics, 42 (1), 53-58. https:// doi.org/10.1017/S1049096509090052

Herring, S.C. (1996). Computer-Mediated Communication: Linguistic, Social and Cross-Cultural Perspectives. Pragmatics and Beyond series. Amsterdam : John Benjamins.

Herring, S.C. (2008). Language and the Internet. In W. Donsbach (Ed.), International Encyclopedia of Communication (pp. 2640-2645).

Herring, S.C. (2013). Discourse in Web 2.0: Familiar, reconfigured, and emergent. Georgetown University Round Table on Languages and Linguistics 2011: Discourse 2.0: Language and new media. (pp. 1-25). Washington, DC : Georgetown University Press. Prepublication version. Retrieved from http://ella. slis.indiana.edu/ herring/GURT.2011.prepub.pdf.

Herring, S.C. (2014). Language and the Internet. In W. Donsbach (Ed.), The concise encyclopedia of communication. Oxford, UK : Wiley-Blackwell. Prepublication version. Retrieved from http://ella.slis.indiana.edu/ herring/concise.pdf.

Herring, S.C. (2015). New frontiers in interactive multimodal communication. In A Georgapoulou \& T. Spilloti (Eds.), The Routledge handbook of language and digital communication (pp. 398-402). London: Routledge.

Herring, S.C., \& Androutsopoulos, J. (2015). Computer-mediated discourse 2.0. In D. Tannen, H.E. Hamilton, \& D. Schiffrin (Eds.), The handbook of discourse analysis, Second Edition (pp. 127-151). Chichester, UK : John Wiley \& Sons. Retrieved from http://info.ils.indiana.edu/ herring/herring. androutsopoulos.2015.pdf.

Himelboim, I., McCreery, S., \& Smith, M. (2013). Birds of a feather tweet together: integrating network and content analyses to examine cross-ideology exposure on Twitter. Journal of Computer-Mediated Communication, 18 (2), 40-60. https://doi.org/10.1111/jcc4.12001 Retrieved from http://onlinelibrary.wiley.com/ doi/10.1111/jcc4.12001/full.

Internet World Stats (2018). Usage and Population Statistics. Retrieved from https:// www.internetworldstats.com/stats.htm. 
Персуазивність у жанрі твіттінг в англомовному політичному...

Kompantseva, L.F. (2008). Internet-lingvistika kognitivno-pragmaticheskiy $i$ lingvokul'torologicheskiy podkhody [Internet-linguistics: cognitive-pragmatic and linguocultural approaches]. Lugansk : Znanie [in Russian].

Lehti, L., \& Laippala, V. (2014). Style in French politicians' blogs: degree of formality. Language@internet, 11. Retrieved from http://www.languageatinternet. org/articles/2014/lehti.

Morozova, O.N. (2011). Politicheskaya internet-kommunikatsiya : yeye rol', funktsii i formy [Political Internet-communication: its role, functions and forms]. Politicheskaya lingvistika - Political linguistics, 1(35), 156-161 [in Russian].

Page, R. (2012). The linguistics of self-branding and micro-celebrity in Twitter: the role of hashtags. Discourse and Communication, 6(2), 181-201.

Petlyuchenko, N.V. (2009). Kharyzmatyka: movna osobystist $i$ dyskurs [Charismatics: the linguistic personality and discourse]. Odesa : Astroprint [in Ukrainian].

Popova, O.V. (2014). Peredvyborchyy dyskurs SSHA v dynamitsi anhliyskoyi movy seredyny XX - pochatku XXI stolit [Pre-election discourse of the USA in the dynamics of the English language in the middle of $\mathrm{XX}$ - beginning of the XXI centuries]. Extended abstract of candidate's thesis. Sumy : SumSU [in Ukrainian].

Snelson, C.L. (2016). Qualitative and Mixed Methods Social Media Research: A Review of the Literature. Journal of Qualitative Methods, 15(1). http://dx.doi. org/10.1177/1609406915624574

Thurlow, C., Lengel, L., \& Tomic, A. (2004). Computer-mediated communication. Newbury Park, CA : Sage.

Valgina, N.S. (2003). Teoriya teksta: uchebnoye posobiye [Text theory: a student guide]. Moscow : Logos [in Russian].

Vashyuk, T.M. (2014). Prahmatyko-funktsionalni vlastyvosti nimetskoho politychnoho dyskursu [Pragmatic and functional properties of German political discourse]. Extended abstract of candidate`s thesis. Lviv : LvivNU [in Ukrainian].

\section{АНОТАЦІЯ}

Стаття присвячена питанням появи нової форми комунікації інтернет-комунікації, а саме політичної інтернет-комунікації, що, в свою чергу, призвело до виникнення нових жанрів, одним з яких $\epsilon$ твіттінг. Активне використання твіттінга з метою комунікації в політичній сфері ставить питання про вивчення мови, а саме способів вираження персуазивності в досліджуваному жанрі, оскільки функція персуазивного мовного впливу є однією з найважливіших функцій політичної інтернет-комунікації з точки зору психолінгвістики.

У процесі дослідження було виявлено ряд вербальних засобів вираження експліцитної та імпліцитної персуазивності. До вербальних засобів експліцитної персуазивності можна віднести використання імперативів та імперативних конструкцій, експліцитних перформативів, конструкцій з модальними дієсловами, коротких речень, слоганів.

Вербальні засоби імпліцитної персуазивності включають в себе риторичні запитання, стверджувальні речення, цитування висловів 
відомих особистостей. До спеціальних мовних засобів, що підсилюють вплив на адресата, також відносять використання еліптичних речень, парцеляції, повтору. Найбільш частотними лексичними стилістичними засобами, які сприяють досягненню основних цілей політичного дискурсу, $\epsilon$ використання метафори, метонімії, іронії, уособлення і оксиморона.

Дослідження дозволило зробити висновок, що англомовна політична інтернет-комунікація характеризується використанням тих же вербальних засобів апелювання, що і традиційна комунікація. Однак можна також виділити засоби, властиві виключно інтернеткомунікації, а саме жанру твіттінг. Методологічною базою дослідження слугували сучасні наукові концепції, розроблені в рамках жанрознавства, психолінгвістики 2.0, віртуального жанрознавства. Відповідно до поставленої мети і завдань були використані як загальнонаукові, так $і$ лінгвістичні методи дослідження.

Ключові слова: спілкування від клавіатури і голоси (звуку) - до екрану і голосу (звуку), психолінгвістика 2.0, політична інтернет-комунікація, інтернет-жанр, твіттінг, персуазивність.

\section{Горошко Елена, Полякова Татьяна. Персуазивность в жанре твиттинг в англоязычном политическом дискурсе}

\section{АННОТАЦИЯ}

Статья посвящена вопросам появления новой формы коммуникации интернет-коммуникации, а именно политической интернеткоммуникации, что, в свою очередь, привело к возникновению новых жанров, одним из которых является твиттинг. Активное использование твиттинга в целях коммуникации в политической сфере ставит вопрос об изучении языка, а именно - способов выражения персуазивности в исследуемом жанре, поскольку функция персуазивного языкового воздействия является одной из важнейших функций политической интернет-коммуникации с точки зрения психолингвистики.

В процессе исследования был выявлен ряд вербальных средств выражения эксплицитной и имплицитной персуазивности. К вербальным средствам эксплицитной персуазивности можно отнести использование императивов и императивных конструкций, эксплицитных перформативов, конструкций с модальными глаголами, коротких предложений, слоганов. Вербальные средства имплицитной персуазивности включают в себя риторические вопросы, утвердительные предложения, цитирование изречений известных личностей. $K$ специальным речевым средствам, усиливающим воздействие на адресата, также относят использование эллиптических предложений, парцелляции, повтора. 
Наиболее частотными лексическими стилистическими средствами, способствующими достижению основных целей политического дискурса, является использование метафоры,метонимии, иронии, олицетворения и оксиморона.

Исследование позволило сделать вывод, что англоязычная политическая интернет-коммуникация характеризуется использованием тех же вербальных средств апеллирования, что и традиционная коммуникация. Однако можно также выделить средства, присущие исключительно интернет-коммуникациии, конкретно, жанру твиттинг. Методологической базой исследования послужили современные научные концепции, разработанные в рамках жанроведения, психолингвистики 2.0, виртуального жанроведения. Согласно поставленной цели и задачам были использованы как общенаучные, так и лингвистические методы исследования.

Ключевые слова: общения от клавиатуры и голоса (звука) - к экрану и голосу (звуку), психолингвистика 2.0, политическая интернеткоммуникация, интернет-жанр, твиттинг, персуазивность. 